\title{
Albumin from Erythrina edulis (Pajuro) as a Promising Source of Multifunctional Peptides
}

\author{
Cleni Palma-Albino ${ }^{1}$, Arturo Intiquilla ${ }^{1,2} \mathbb{D}$, Karim Jiménez-Aliaga $\left.{ }^{1, *} \mathbb{(}\right)$, Nathaly Rodríguez-Arana ${ }^{1}$, \\ Estela Solano ${ }^{1}$, Eduardo Flores ${ }^{1}$, Amparo Iris Zavaleta ${ }^{1}{ }^{D}$, Víctor Izaguirre ${ }^{1}$ and Blanca Hernández-Ledesma ${ }^{3, *}$ (D) \\ 1 Grupo de Investigación BIOMIAS, Departament of Biochemistry, Facultad de Farmacia y Bioquímica, \\ Universidad Nacional Mayor de San Marcos, Jr. Puno 1002, Lima 4559, Peru; \\ cleni.palma@unmsm.edu.pe (C.P.-A.); aintiquillaq@unmsm.edu.pe (A.I.); \\ nathaly.rodriguez@unmsm.edu.pe (N.R.-A.); stelasolano26@gmail.com (E.S.); efloresj@unmsm.edu.pe (E.F.); \\ azavaletap@unmsm.edu.pe (A.I.Z.); vizaguirrep@unmsm.edu.pe (V.I.) \\ 2 Departamento de Ciencia de los Alimentos y Tecnología Química, Facultad de Ciencias Químicas \\ y Farmacéuticas, Universidad de Chile, Santos Dumont 946, Santiago de Chile 8380492, Chile \\ 3 Department of Bioactivity and Food Analysis, Instituto de Investigación en Ciencias de la \\ Alimentación (CIAL, CSIC-UAM, CEI UAM+CSIC), Nicolás Cabrera 9, 28049 Madrid, Spain \\ * Correspondence: kjimeneza@unmsm.edu.pe (K.J.-A.); b.hernandez@csic.es (B.H.-L.)
}

\section{check for}

updates

Citation: Palma-Albino, C.; Intiquilla, A.; Jiménez-Aliaga, K.; Rodríguez-Arana, N.; Solano, E.; Flores, E.; Zavaleta, A.I.; Izaguirre, V.; Hernández-Ledesma, B. Albumin from Erythrina edulis (Pajuro) as a Promising Source of Multifunctional Peptides. Antioxidants 2021, 10, 1722. https://doi.org/10.3390/

antiox10111722

Academic Editor: Stanley Omaye

Received: 7 October 2021

Accepted: 26 October 2021

Published: 28 October 2021

Publisher's Note: MDPI stays neutral with regard to jurisdictional claims in published maps and institutional affiliations.

Copyright: (c) 2021 by the authors. Licensee MDPI, Basel, Switzerland. This article is an open access article distributed under the terms and conditions of the Creative Commons Attribution (CC BY) license (https:// creativecommons.org/licenses/by/ $4.0 /)$.

\begin{abstract}
Multifunctional peptides, capable of acting on different body systems through multiple mechanisms of action, offer many advantages over monofunctional peptides, including lower adverse side effects and costs. Erythrina edulis (pajuro) is a legume with a large number of high-quality proteins, of which their potential as a source of antioxidant peptides has been recently reported. In this study, the behavior of these proteins under a sequential enzymatic hydrolysis with digestive and microbial enzymes was investigated by evaluating the multi-functionality of the hydrolyzates. The albumin hydrolyzates obtained after the action of pepsin, pancreatin, and Alcalase showed antioxidant, angiotensin-converting enzyme (ACE), $\alpha$-amylase, $\alpha$-glucosidase, and dipeptidyl peptidase (DPP)-IV inhibitory activities. The radical scavenging properties of the hydrolyzate could be responsible for the potent protective effects observed in $\mathrm{FeSO}_{4}$-induced neuroblastoma cells. The findings support the role of pajuro protein as an ingredient of functional foods or nutraceuticals for health promotion and the prevention of oxidative stress, hypertension, and metabolic alteration-associated chronic diseases.
\end{abstract}

Keywords: Erythrina edulis; legume proteins; sequential enzymatic digestion; multifunctional peptides

\section{Introduction}

Proteins are vital macronutrients involved in body maintenance and growth; thus, the search for high-quality proteins and their inclusion into the daily diet has become a prevalent research area. To meet consumer trends in limiting the intake of animal-derived proteins, nutritionists, researchers, and food industries are exploring novel and sustainable protein sources. Among them, traditional and under-utilized plants are becoming popular as a source of proteins that provide important nutritional, technological, and functional properties [1]. In addition to these attributes, proteins also provide multiple health benefits through their impact on specific biochemical pathways. Most of these activities result from peptides encrypted within the parent protein sequence that, once released by enzymatic hydrolysis, gastrointestinal digestion, or food processing, are absorbed by intestinal cells and transported to their target organs, and then, can exert their biological effects [2]. Over the years, numerous bioactive peptides have been identified from plant foods protein hydrolyzates. Their diversified structures explain the wide range of activities demonstrated for these peptides, such as antioxidant, anti-inflammatory, anti-hypertensive, anti-microbial, anti-diabetic, and chemo-preventive activities, among others [3-5]. These reported effects demonstrate the potential of bioactive peptides to be used as ingredients of functional 
foods and/or nutraceuticals aimed at promoting health and reducing the risk of suffering from non-communicable diseases (NCDs) [6].

NCDs, such as cardiovascular and neurodegenerative disorders, diabetes, and cancer are the main cause of mortality and incapacity worldwide [7]. The environmental factors and, mainly, the diet are the major contributing factors to most of these diseases. While the intake of processed foods and sugar-sweetened beverages has been correlated with a higher risk of NCDs, a healthy diet including functional foods has been found to reduce or even prevent several of these disorders $[7,8]$. It has been demonstrated that most of NCDs show common etiological characteristics including oxidative stress, hypertension, inflammation, and metabolic alterations [9]. Thus, acting against one or more of these pathophysiological conditions with natural derived compounds has become a promising alternative for the prevention/management of NCDs. Among these compounds, multifunctional peptides, defined as peptides with the ability to exert more than one physiological effect by affecting several targets, represent an emerging area with multiple applications [10]. They may be considered enhancements compared with mono-functional peptides, which exert one single activity, owing to reduced negative side effects and costs [11].

Erythrina edulis (pajuro or chachafruto) is a legume with a wide variety of uses, from the human (seeds) and animal (forage) diet to the recovery of nitrogen from the soil. This plant is recognized by its high nutritional value, containing a superior content of highquality and digestibility proteins (18-25\%) [12]. Moreover, the seed has been found to be rich in carbohydrates $(51 \%)$ and micronutrients, such as minerals (phosphorus, iron, sulfur, sodium, potassium, manganese, and calcium) and vitamins (vitamin C, thiamin, niacin, and riboflavin) [12]. In addition of its nutritional attributes, pajuro has been traditionally used for medical purposes as a diuretic, hypotonic, and osteoporosis prophylactic [13]. These attributes have been associated with the presence of phytochemicals such as saponins, alkaloids, flavonoids (mainly quercetin), and polyphenols (mainly phloroglucinol) [14]. Despite its high protein content, information concerning the biological properties of peptides contained in their sequences is still scarce and limited to antioxidant activity. Thus, in a previous study carried out in our group, the radical scavenging activity of E. edulis protein hydrolyzates with different enzymes was demonstrated [13], and peptides contained in the Alcalase hydrolyzate were identified as potentially responsible for the observed effects [15]. However, no data on other activities have been reported. Thus, the aim of this work was to separate pajuro protein into its different fractions and to hydrolyze them by a sequential hydrolytic reaction with both digestive and microbial enzymes. The multi-functionality of hydrolyzates was investigated, focusing on their in vitro anti-hypertensive, anti-diabetic, and neuroprotective effects on both biochemical and cell models.

\section{Materials and Methods}

\subsection{Materials}

E. edulis (pajuro) seeds were collected in Otuzco-La Libertad (Peru) in 2016. Pepsin from porcine gastric mucosa (EC 3.4.23.1; 0.7 International Pharmaceutical Federation units (FIP) $\mathrm{U} / \mathrm{mg}$ protein), pancreatin from porcine pancreas (0.35 FIP-U/mg protein), iron II sulfate heptahydrate, ortho-phthalaldehyde (OPA), 3,5-dinitrosalicylic acid, sodium potassium tartrate, and thiobarbituric acid (TBA) were purchased from Merck Millipore Corp. (Darmstadt, Germany). Alcalase $2.4 \mathrm{U} / \mathrm{g}$ protein from Bacillus licheniformis was acquired from Novozymes (Bagsvaerd, Denmark). Bovine seroalbumin (BSA), 2,2'-azino-bis(3ethylbenzothiazoline-6-sulfonic acid) $\left(\mathrm{ABTS}^{\bullet+}\right)$, 6-hydroxy-2,5,7,8-tetramethylchroman-2carboxylic acid (Trolox), disodium fluorescein (FL), 2,2'-azobis (2-amidinopropane dihydrochloride) (AAPH), angiotensin converting enzyme (ACE) from lung rabbit, hippurylhistidyl-leucine (HHL), captopril, type VI-B $\alpha$-amylase from porcine pancreas, 4-nitrophenyl $\alpha$-D-glucopyranoside, acarbose, $\alpha$-glucosidase from Saccharomyces cerevisiae, dipeptidyl peptidase IV (DPP-IV) Inhibitor Screening Kit MAK203, sitagliptin, type II lipase from porcine pancreas, sodium deoxycholate, orlistat, 4-nitrophenyl palmitate, RPMI-1640 Medium, fetal bovine serum (FBS), L-glutamine solution, sodium pyruvate, non-essential 
amino acids (NEAA), gentamicin, 3-[4,5-dimethylthiazol-2-yl]-2,3-diphenyl tetrazolium bromide (MTT), sodium pyruvate, $\beta$-nicotinamide adenine dinucleotide (NADH), and $2^{\prime}$ $7^{\prime}$ dichlorofluorescin diacetate (DCFA-DA) were purchased from Sigma-Aldrich (St. Louis, $\mathrm{MO}, \mathrm{USA})$. All other reagents were of analytical grade.

\subsection{Obtention of Seed Flour and Analysis of Its Proximate Composition}

Once cleaned, peeled, and cut into small pieces, seeds were dried at $40{ }^{\circ} \mathrm{C}$ until reaching a constant weight, ground in a domestic mill, and filtered using mesh number 60 to obtain a homogenous flour sample. The AOAC methods for moisture (934.01), fat (930.09), ash (930.05), crude fiber (934.10), and protein (978.04) were performed to determine the proximate composition of the flour. The protein value was calculated as nitrogen $\times 6.25$, and nitrogen-free extract was estimated as the difference.

\subsection{Protein Fractionation of Seed Flour}

The separation of different protein fractions (albumin, globulin, prolamin, and glutelin) from E. edulis seed flour was carried out following the method reported by Chavan et al. [16], with some modifications. Firstly, the seed flour was suspended in Milli-Q water at a ratio of 1:6 (w/v), shaken for $60 \mathrm{~min}$ at $80 \mathrm{rpm}$, and centrifuged at $14,000 \times \mathrm{g}$ for $20 \mathrm{~min}$ at $4{ }^{\circ} \mathrm{C}$. The supernatant was collected and the retentate was subjected to three washing steps with Milli-Q water at a ratio of 1:3 $(p / v)$ under the same conditions, collecting the corresponding supernatants. The $\mathrm{pH}$ of the supernatants was adjusted to 4.5 with $1 \mathrm{M} \mathrm{HCl}$, and the solution was centrifuged at $14,000 \times \mathrm{g}$ for $20 \mathrm{~min}$ at $4{ }^{\circ} \mathrm{C}$. The retentate was collected, re-suspended in distilled water, and its $\mathrm{pH}$ was adjusted to 7.0 with $1 \mathrm{M} \mathrm{NaOH}$. The albumin fraction was freeze-dried and kept at $-20^{\circ} \mathrm{C}$ until its further use. The extraction of globulin, prolamin, and glutelin was carried out following the same steps, only with a change in the extraction solvent: $5 \% \mathrm{NaCl}$ for globulin, $70 \%$ ethanol for prolamin, and $0.01 \mathrm{M} \mathrm{NaOH}$ for glutelin.

The amino acids content of protein fractions was analyzed by cation exchange chromatography using a Biochrom 30 series Amino Acid Analyser (Biochrom, Cambridge, MA, USA) after automatic pre-column derivatization of samples with OPA and measurement of the absorbance at $440 \mathrm{~nm}$. The samples were previously hydrolyzed with $6 \mathrm{M} \mathrm{HCl}$ for $21 \mathrm{~h}$ at $110^{\circ} \mathrm{C}$. Two replicates for each sample were performed. The results were expressed as mean (g of amino acid/100 g protein).

The protein profile of protein fractions was analyzed by SDS-PAGE using $12 \%$ acrylamide gels (Merck Millipore Corp.). Samples were mixed with a sample buffer $[60 \mathrm{mM}$ Tris-HCl pH 6.8, 25\% glycerol $(v / v), 2 \%$ sodium dodecyl sulfate (SDS) $(p / v), 14.4 \mathrm{mM}$ 2-mercaptoethanol, and $0.1 \%$ 2-bromophenol $(p / v)]$, heated for $4 \mathrm{~min}$ at $100{ }^{\circ} \mathrm{C}$, and cooled to room temperature. $10 \mu \mathrm{g}$ of protein was loaded onto gels and run in a Mini-Protean Tetra Cell Electrophoresis System (Bio-Rad, Richmond, CA, USA). The conditions were set at $200 \mathrm{~V}$, and the gels were run for $45 \mathrm{~min}$. After electrophoresis, the gels were stained with Coomassie Blue for $60 \mathrm{~min}$, destained with a $10 \%$ acetic acid $-10 \%$ methanol solution for $12 \mathrm{~h}$ and photographed using a digital camera. A pajuro protein concentrate previously obtained [15] was used as a standard.

\subsection{Enzymatic Hydrolysis of Pajuro Protein Fractions}

A $4 \%(w / v)$ suspension of protein fractions in water was shaken at $100 \mathrm{rpm}$ for $30 \mathrm{~min}$ and centrifuged at $2500 \times g$ for $10 \mathrm{~min}$. The collected supernatant was heated at $90{ }^{\circ} \mathrm{C}$ for $10 \mathrm{~min}$, and its $\mathrm{pH}$ was adjusted at 1.9 with $3 \mathrm{M} \mathrm{HCl}$. After adding pepsin at an enzyme: substrate (E/S) ratio of 1:50 (v/v), the reaction was performed for $30 \mathrm{~min}$ at $37^{\circ} \mathrm{C}$ with constant stirring at $80 \mathrm{rpm}$. The enzyme was inactivated by increasing the $\mathrm{pH}$ to 7.8 with $1 \mathrm{M} \mathrm{NaOH}$. Then, pancreatin was added $(\mathrm{E} / \mathrm{S}=1: 50, v / v)$ and the mixture was incubated for $60 \mathrm{~min}$ at $37^{\circ} \mathrm{C}$ with constant stirring at $80 \mathrm{rpm}$. After stopping the reaction by addition of $150 \mathrm{mM} \mathrm{Na}_{2} \mathrm{CO}_{3}$ to adjust the $\mathrm{pH}$ to 8.5 , Alcalase was added ( $\left.\mathrm{E} / \mathrm{S}=1 / 200, v / v\right)$, and the mixture was incubated for $120 \mathrm{~min}$ at $50^{\circ} \mathrm{C}$ and $80 \mathrm{rpm}$. Aliquots were withdrawn at 
$0,15,30,60$, and $120 \mathrm{~min}$, inactivating the enzyme by heating at $100{ }^{\circ} \mathrm{C}$ for $10 \mathrm{~min}$. The hydrolyzates were rapidly cooled and centrifuged at $10,000 \times g$ for $10 \mathrm{~min}$ at $4{ }^{\circ} \mathrm{C}$. The supernatants were freeze-dried and stored at $-20^{\circ} \mathrm{C}$. The degree of hydrolysis $(\mathrm{DH})$ was determined following the method reported by Nielsen et al. [17] The protein content was determined by the bicinchoninic acid (BCA, Pierce, Rockford, IL, USA) method, using BSA as a standard protein.

\subsection{Antioxidant Activity}

The ABTS $^{\bullet+}$ scavenging activity was determined according to the enhanced improved ABTS $^{\bullet+}$ protocol described by Re et al. [18]. A volume of $980 \mu \mathrm{L}$ of diluted ABTS ${ }^{\bullet+}$ solution and $20 \mu \mathrm{L}$ of either PBS (blank), Trolox (2-25 $\mu \mathrm{M})$ (standard) or sample were mixed, and the absorbance was measured at $734 \mathrm{~nm}$ after $7 \mathrm{~min}$-incubation at room temperature. To calculate the Trolox equivalent antioxidant capacity (TEAC), the gradient of the plot of the percentage inhibition of absorbance versus protein concentration was divided by the gradient of the plot for Trolox. TEAC values were expressed as $\mu$ mol Trolox equivalent (TE)/mg of protein.

The oxygen radical absorbance capacity (ORAC) was determined following the protocol described by Hernández-Ledesma et al. [19], with some modifications. Briefly, the mixture $(200 \mu \mathrm{L})$ containing FL $(30 \mathrm{nM})$, AAPH $(12 \mathrm{mM})$, and either antioxidant [Trolox $(0-5 \mathrm{nM})$ or sample (at different concentrations)], was incubated at $37^{\circ} \mathrm{C}$ in $75 \mathrm{mM}$ phosphate buffer ( $\mathrm{pH} 7.4$ ). Then, we recorded the fluorescence at 485 and $520 \mathrm{~nm}$ of excitation and emission, respectively, at every $2 \mathrm{~min}$ for $120 \mathrm{~min}$ in an Infinite M200 Pro plate reader (Tecan Group AG, Männendorf, Switzerland) controlled by Icontrol software version 1.11.10. ORAC values were expressed as $\mu \mathrm{mol} \mathrm{TE} / \mathrm{mg}$ of protein.

\subsection{Angiotensin-Converting Enzyme (ACE) Inhibitory Activity}

The in vitro ACE inhibitory activity of hydrolyzates was measured using the methodology described by Hayakari and coworkers [20], with some modifications. The reaction mixture $(200 \mu \mathrm{L})$ containing $1 \mathrm{mU}$ ACE, $1.25 \mathrm{mM} \mathrm{HHL}$, and sample or captopril (used as standard) at different concentrations was incubated at $37^{\circ} \mathrm{C}$ for $60 \mathrm{~min}$. The reaction was stopped by heating at $100{ }^{\circ} \mathrm{C}$ for $10 \mathrm{~min}$. A volume of $100 \mu \mathrm{L}$ of a $3 \%$ solution of trichloro-5-triazine/dioxan was added, and the mixture was shaken and centrifuged at $1000 \times g$ for $10 \mathrm{~min}$. Then, the absorbance was measured at $382 \mathrm{~nm}$ in an Infinite M200 Pro plate reader (Tecan Group AG). The activity was expressed as \% (compared with control) and $\mathrm{IC}_{50}$ or protein concentration required to inhibit the ACE activity by $50 \%$.

\subsection{In Vitro Anti-Diabetic Activity}

The $\alpha$-amylase inhibition assay was carried out following the methods previously described [21,22], with some modifications. The reaction mixture $(200 \mu \mathrm{L})$ containing $\alpha$-amylase ( $800 \mathrm{mU}), 0.125 \%$ starch, and sample or standard (at different concentrations) in $0.1 \mathrm{M}$ phosphate buffer ( $\mathrm{pH}$ 6.9) was incubated at $37^{\circ} \mathrm{C}$ for $30 \mathrm{~min}$. A volume of $100 \mu \mathrm{L}$ of a solution containing 1\% 3,5-dinitrosalicylic acid and 30\% sodium potassium tartrate in $0.4 \mathrm{M} \mathrm{NaOH}$ was added, shaking the mixture, and incubating it at $100{ }^{\circ} \mathrm{C}$ for $10 \mathrm{~min}$. The absorbance was measured at $540 \mathrm{~nm}$ in an Infinite M200 Pro plate reader (Tecan Group AG). The inhibition percentage was calculated relative to the negative control having $100 \%$ enzyme activity.

The $\alpha$-glucosidase inhibition assay was performed following previous methods [23,24], with some modifications. Briefly, $200 \mu \mathrm{L}$ of reaction mixture containing $10 \mathrm{mU} \alpha$-glucosidase, $5 \mathrm{mM}$ 4-nitrophenyl- $\alpha$-D-glucopyranoside, and sample or standard acarbose (at different concentrations) in $0.1 \mathrm{M}$ phosphate buffer ( $\mathrm{pH}$ 6.9) was incubated at $25{ }^{\circ} \mathrm{C}$ for $30 \mathrm{~min}$, reading the absorbance each $2 \mathrm{~min}$ at $405 \mathrm{~nm}$ in the Infinite M200 Pro plate reader (Tecan Group AG). Percent inhibition was calculated relative to the negative control having 100\% enzyme activity. 
The DPP-IV inhibitory activity was determined using the DPP-IV Inhibitor Screening Kit MAK203. The reaction mixture $(100 \mu \mathrm{L})$, containing $5 \mu \mathrm{L}$ of enzymatic solution, sample or standard sitagliptin (at different concentrations), and $5 \mu \mathrm{L}$ of substrate, was incubated at $37^{\circ} \mathrm{C}$ for $30 \mathrm{~min}$, and the fluorescence was recorded each $2 \mathrm{~min}$ at $\lambda$ excitation and $\lambda$ emission of 360 and $460 \mathrm{~nm}$, respectively, in the Infinite M200 Pro plate reader (Tecan Group AG). The results were expressed as $\mathrm{IC}_{50}$ value or protein concentration needed to inhibit 50\% DPP-IV activity.

\subsection{Pancreatic Lipase Inhibitory Activity}

The pancreatic lipase inhibitory assay was performed following methods previously described [25,26], with some modifications. The reaction mixture $(200 \mu \mathrm{L})$ contained $50 \mathrm{mM}$ sodium deoxycholate, $0.2 \mathrm{mM} \mathrm{CaCl}_{2}, 12 \mathrm{mU}$ type 2 pancreatic lipase, sample or standard orlistat (at different concentrations), and $0.125 \mathrm{mM}$ substrate 4-nitrophenyl palmitate in $50 \mathrm{mM}$ phosphate buffer ( $\mathrm{pH} 8.0$ ). The mixture was incubated at $37^{\circ} \mathrm{C}$ for $60 \mathrm{~min}$, and the absorbance at $405 \mathrm{~nm}$ was measured every $2 \mathrm{~min}$ in the Infinite M200 Pro plate reader (Tecan Group AG). The inhibition percentage was calculated relative to the negative control having $100 \%$ enzyme activity.

\subsection{Protective Effects in SH-SY5Y Cells}

\subsubsection{Cell Culture}

Human neuroblastoma SH-SY5Y cells were obtained from the American Type Culture Collection (ATCC, HTB-38, Rockville, MD, USA). The cells were maintained in RPMI-1640 medium supplemented with 10\% FBS, $2 \mathrm{mM}$ L-glutamine solution, $1 \mathrm{mM}$ sodium pyruvate, $1 \mathrm{mM}$ non-essential amino acids, and $50 \mathrm{ug} / \mathrm{mL}$ gentamicin. Cells were incubated at $37^{\circ} \mathrm{C}$ under a $5 \% \mathrm{CO}_{2} / 95 \%$ air at constant humidity.

\subsubsection{Effects on Cell Viability}

Cell viability was determined using the MTT assay. SH-SY5Y cells were seeded onto 96-well plates at a density of $2 \times 10^{4}$ cells/well in complete medium with $1 \%$ FBS and incubated for $16 \mathrm{~h}$ at $37^{\circ} \mathrm{C}$. Afterwards, culture medium was removed, and the sample was added (at concentration between 0.25 and $2.0 \mathrm{mg} / \mathrm{mL}$ ), incubating the plate for $24 \mathrm{~h}$. After removing the supernatant, a MTT solution $(2 \mathrm{mg} / \mathrm{mL}$ in PBS) was added, and the plate was incubated for $60 \mathrm{~min}$ at $37^{\circ} \mathrm{C}$. The supernatant was aspirated, insoluble formazan crystals formed were dissolved in dimetilsulfoxide (DMSO), and the absorbance was measured at $570 \mathrm{~nm}$ in the Infinite M200 Pro plate reader (Tecan Group AG). The results were expressed as percentage of the control, considered as $100 \%$.

\subsubsection{Protective Effects against Oxidative Stress Induced by $\mathrm{FeSO}_{4}$}

For this assay, SH-SY5Y cells were seeded onto 48-well plates at a density of $4 \times 10^{4}$ cells / well in complete medium with $1 \%$ FBS and incubated for $16 \mathrm{~h}$ at $37^{\circ} \mathrm{C}$. The medium was aspirated, and cells were washed with PBS. Then, hydrolyzate (concentrations of 0.1, 0.5, and $1.0 \mathrm{mg} / \mathrm{mL}$ ) and $10 \mathrm{mM}$ glucose were added, and cells were incubated for $30 \mathrm{~min}$. Once the supernatant was removed, the cells were maintained in complete medium with $1 \%$ FBS for $6 \mathrm{~h}$ at $37^{\circ} \mathrm{C}$. Intracellular ROS levels were quantified following the method described by LeBel et al., using dichlorofluorescin (DCFH) as a fluorescent probe [27]. The medium was aspirated, and $100 \mu \mathrm{L}$ of a solution containing $10 \mathrm{mM}$ DCFA-DA and $10 \mathrm{mM}$ glucose in PBS was added to the wells, and the plate was incubated at $37^{\circ} \mathrm{C}$ for $30 \mathrm{~min}$. Then, the supernatant was discarded, cells were washed with PBS, and $200 \mu \mathrm{M}$ $\mathrm{FeSO}_{4}$ in complete medium with $1 \%$ FBS was added, measuring the fluorescence after 60 min-exposure to the ROS inductor in the Infinite M200 Pro plate reader (Tecan Group AG). The excitation and emission wavelengths were 485 and $530 \mathrm{~nm}$, respectively. The results were expressed as ROS levels (\% compared with the control, considered as 100\%). 


\subsubsection{Determination of Thiobarbituric Acid Reaction Substances (TBARS)}

SH-SY5Y cells were seeded onto $60 \mathrm{~mm}$ dishes at a density of $7.5 \times 10^{5}$ cells/dish in complete medium with 10\% FBS and incubated for $72 \mathrm{~h}$. Then, the supernatant was discarded and the hydrolyzate, dissolved in PBS with $10 \mathrm{mM}$ glucose, was added to the wells (final concentration of $0.5,1.0$, and $1.5 \mathrm{mg} / \mathrm{mL}$ ). The plate was incubated for $30 \mathrm{~min}$ and then the cells were washed with PBS and stimulated with $200 \mu \mathrm{M} \mathrm{FeSO}$ for $3 \mathrm{~h}$ in complete medium with $1 \%$ FBS. Afterwards, both the supernatant and cell pellet were collected. The cell pellet was resuspended in $50 \mathrm{mM}$ phosphate buffer ( $\mathrm{pH} 7.4)$ and subjected to ultrasonication. $250 \mu \mathrm{L}$ of $1 \%$ phosphoric acid and $75 \mu \mathrm{L}$ of TBA were added to $30 \mu \mathrm{L}$ of cellular suspension, and the mixture was incubated $100{ }^{\circ} \mathrm{C}$ for $45 \mathrm{~min}$. Once cooled and centrifuged at $3000 \times g$ for $5 \mathrm{~min}$ a $4{ }^{\circ} \mathrm{C}$, the fluorescence was measured at excitation and emission wavelengths of 485 and $530 \mathrm{~nm}$, respectively, in the Infinite M200 Pro plate reader (Tecan Group AG). A standard curve with malondialdehyde (MDA) was used. The results were expressed as nmol MDA/mg protein.

\subsubsection{Determination of Lactate Dehydrogenase (LDH) Activity}

A volume of $100 \mu \mathrm{L}$ of supernatant previously collected was mixed with $100 \mu \mathrm{L}$ of the reaction solution containing $0.18 \mathrm{mM}$ sodium pyruvate and $0.6 \mathrm{mM} \mathrm{NADH}$ in phosphate buffer ( $50 \mathrm{mM}, \mathrm{pH}$ 7.4). After 2 min-incubation, the fluorescence was measured at excitation and emission wavelengths of 360 and $460 \mathrm{~nm}$, respectively, in the Infinite M200 Pro plate reader (Tecan Group AG). The results were expressed as LDH activity (\% compared with the control, considered as $100 \%$ ).

\subsection{Statistical Analysis}

All data were analyzed in 3 independent experiments, and results were expressed as the mean \pm standard deviation (SD) or standard error of the mean (SEM). Data were analyzed using a one-way analysis of variance (ANOVA) followed by the Tukey test for multiple comparisons. All analyses were run with the program GraphPad Prism v.6. or SigmaPlot 14.5 Statistical, significance was defined as $p<0.05$.

\section{Results and Discussion}

\subsection{Obtention and Fractionation of E. edulis Seed Flour}

The values of ash, fat, and fiber content determined in the E. edulis seed flour were $39.5 \mathrm{~g} / \mathrm{kg}, 13.1 \mathrm{~g} / \mathrm{kg}$, and $58.9 \mathrm{~g} / \mathrm{kg}$, respectively. The protein content of the flour $(186.0 \mathrm{~g} / \mathrm{kg})$ was comparable to that $(184 \mathrm{~g} / \mathrm{kg})$ determined by Arango Bedoya et al. [12]. The flour was fractionated by using different solvents into albumin, globulin, prolamin, and glutelin fractions, obtaining yield values of $3.93,0.25,0.02$, and $3.80 \%$, respectively. Table 1 shows the amino acid composition of the flour and extracted fractions.

Table 1. Amino acid composition (g/100 g of protein) of Erythrina edulis flour and its protein fractions.

\begin{tabular}{ccccccc}
\hline \multirow{2}{*}{ Amino Acid } & \multicolumn{7}{c}{ Content (g/100 g Protein) } \\
\cline { 2 - 6 } & Seed Flour & Albumin & Globulin & Glutelin & Prolamin & FAO \\
\hline Essential & & & & & & \\
Lys & 2.06 & 4.39 & 4.48 & 3.20 & 1.88 & 5.2 \\
Trp & n.d. & n.d. & n.d. & n.d. & n.d. & 0.7 \\
Phe & 1.98 & 4.25 & 4.01 & 3.12 & 1.57 & $4.6^{\text {a }}$ \\
Tyr & 1.23 & 3.82 & 3.92 & 2.63 & 0.74 & \\
Met & 0.38 & 1.18 & 1.22 & 0.93 & 0.39 & $2.6^{\mathrm{b}}$ \\
Cys & 0.89 & 1.02 & 1.03 & 0.49 & 0.45 & \\
Thr & 1.19 & 2.26 & 2.41 & 1.82 & 0.89 & 2.7 \\
Leu & 2.68 & 6.11 & 5.98 & 4.47 & 2.43 & 6.3 \\
Ile & 1.16 & 2.56 & 2.50 & 1.77 & 1.08 & 3.1 \\
Val & 2.11 & 3.62 & 3.38 & 2.36 & 1.68 & 4.2 \\
\hline
\end{tabular}


Table 1. Cont.

\begin{tabular}{ccccccc}
\hline \multirow{2}{*}{ Amino Acid } & \multicolumn{5}{c}{ Content (g/100 g Protein) } \\
\cline { 2 - 6 } & Seed Flour & Albumin & Globulin & Glutelin & Prolamin & FAO \\
\hline Non essential & & & & & \\
Asx ${ }^{\text {c }}$ & 4.78 & 9.57 & 8.99 & 6.50 & 3.44 & \\
Glx & 5.50 & 11.98 & 11.65 & 8.05 & 4.15 & \\
Ser & 2.24 & 5.11 & 5.16 & 3.57 & 1.66 & \\
His & 1.50 & 1.90 & 1.88 & 1.59 & 0.68 & \\
Arg & 1.05 & 3.58 & 3.63 & 2.45 & 0.86 & \\
Ala & 1.68 & 3.30 & 2.99 & 2.62 & 1.59 & \\
Pro & 2.19 & 4.17 & 3.98 & 2.74 & 1.58 & \\
Gly & 1.69 & 3.83 & 3.45 & 2.55 & 1.43 & \\
TAA & 34.31 & 72.65 & 70.66 & 50.86 & 26.50 & \\
HAA & 14.30 & 30.03 & 29.01 & 21.13 & 11.51 & \\
AAA & 3.21 & 8.07 & 7.93 & 5.75 & 2.31 & \\
\hline
\end{tabular}

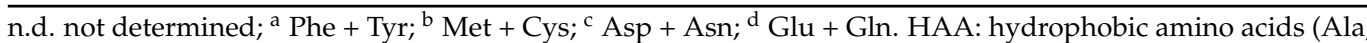
Val, Ile, Leu, Tyr, Phe, Trp, Met, Pro, and Cys); TAA: total amino acids; AAA: aromatic amino acids (Phe, Trp, and Tyr). Data are the mean of two determinations.

The amino acid Trp was not identified under the conditions used because of its destruction by acid hydrolysis. In the flour, Leu, Val, and Lys were the most abundant essential amino acids (EAA), with values of $2.68 \pm 0.24,2.11 \pm 0.13$, and $2.06 \pm 0.18 \mathrm{~g} / 100 \mathrm{~g}$ of protein, respectively. Asp + Asn and Glu + Gln were the most abundant non-essential amino acids (NEAA), with values of $4.78 \pm 0.37$ and $5.50 \pm 0.55 \mathrm{~g} / 100 \mathrm{~g}$ of protein, respectively, as it has been reported for other legumes such as pea [28]. The ratio of EAA to total amino acid (TAA) was $40 \%$, and the ratio of EAA to NEAA was $66 \%$ that were similar to the protein reference pattern (EAA/TAA, 40\%; EAA/NEAA, 60\%) raised by FAO/WHO. An increase in the TAA content was observed for albumin $(111.7 \%)$, globulin $(105.9 \%)$, and glutelin $(48.2 \%)$ fractions. However, a reduction by $22.7 \%$ was observed for prolamin fraction. Nevertheless, the ratios EAA/TAA and EAA/NEAA were maintained in four protein fractions.

SDS-PAGE was run to analyze the protein profile of the protein concentrate and fractions (Figure 1). This analysis revealed a high number of bands from 16 to $90 \mathrm{kDa}$, being bands corresponding to proteins with molecular weight of 18,20,25, 50, and $58 \mathrm{kDa}$ clearly visible. The intensity of the $25 \mathrm{kDa}$ and $18-\mathrm{kDa}$ bands was more intense in the globulin and prolamin fractions, respectively.

\subsection{Enzymatic Hydrolysis of Pajuro Protein Fractions}

Albumin, globulin, and glutelin fractions obtained from pajuro seed flour were sequentially hydrolyzed by pepsin for $30 \mathrm{~min}$, pancreatin for $60 \mathrm{~min}$, and alcalase for 15, 30, 60 , and $120 \mathrm{~min}$. Digestion efficiency was monitored by the estimation of the DH. Figure 2A shows the $\mathrm{DH}$ of hydrolyzates obtained after pepsin hydrolysis $(\mathrm{PH})$, pepsin + pancreatin hydrolysis (PPH), and pepsin + pancreatin + alcalase hydrolysis at different times (PPHA15, PPHA30, PPHA60, and PPHA120). As shown in the Figure 2A, the DH slightly increased during the pepsin + pancreatin hydrolysis of the albumin and globulin fractions. The $\mathrm{DH}$ value reached in the albumin PPH (7.81\%) was lower to that determined recently by Moscoso-Mújica et al. for hydrolyzates obtained after pepsin-pancreatin co-incubation with albumin from Chenopodium pallidicaule Aellen (kanihua) for $1 \mathrm{~h}$ (DH of 22\%) [29]. In the case of glutelin fraction, the increase was moderated, reaching a DH value for PPH of $20.07 \%$. This value was similar to those reported for raw peanut protein hydrolyzed by pepsin for $30 \mathrm{~min}$ and pancreatin for $24 \mathrm{~h}(21.4 \%)$ [30], and for Phaseolus lunatus (lima bean) protein hydrolyzed by pepsin for $45 \mathrm{~min}$ and pancreatin for $45 \mathrm{~min}(22.09 \%)$ [31]. 


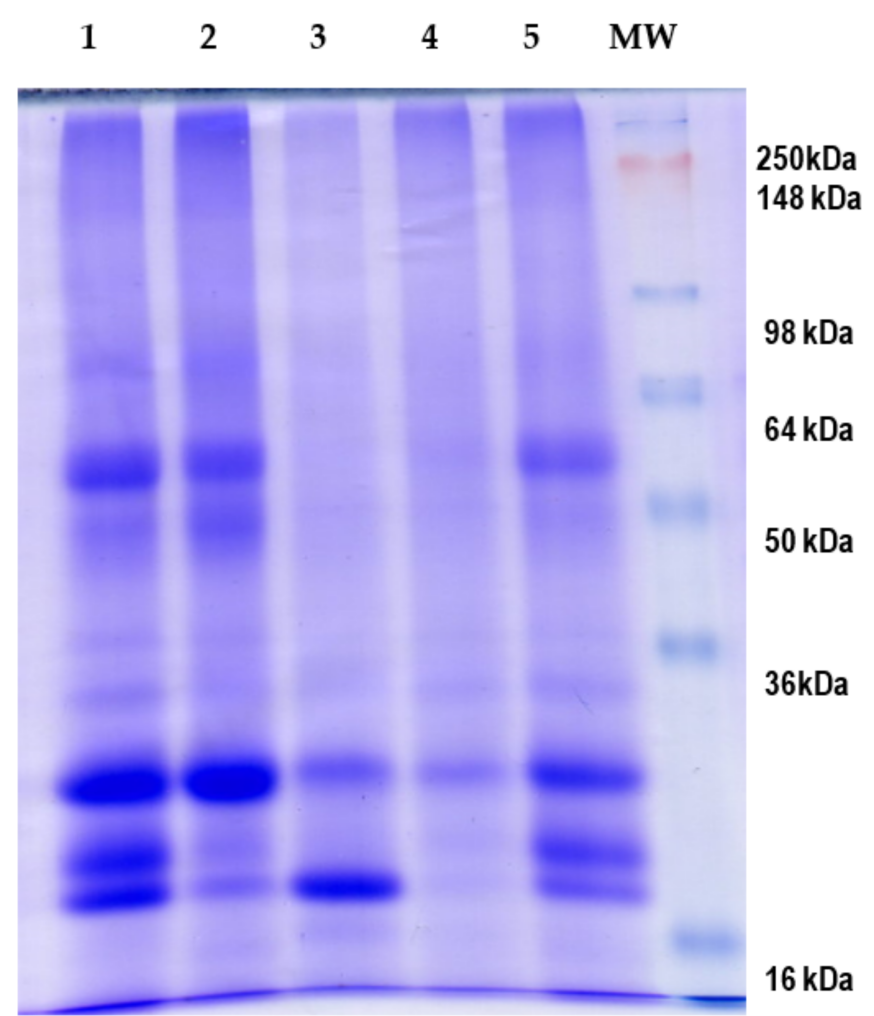

Figure 1. SDS-PAGE analysis of protein fractions obtained from Erythrina edulis (pajuro): (1) albumin; (2) globulin; (3) prolamin; (4) glutelin. (5) Protein concentrate. MW: molecular weight marker SeeBlue ${ }^{\mathrm{TM}}$ Plus2 Prestained.

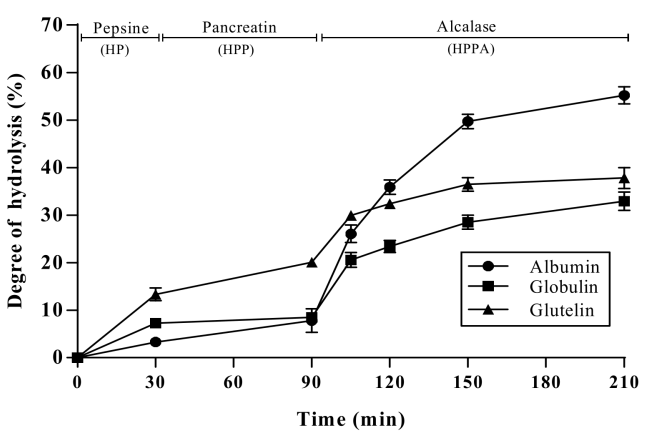

(A)

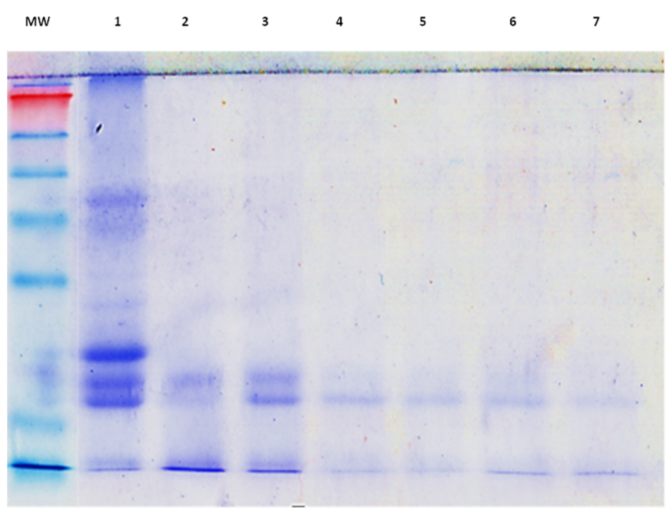

(B)

Figure 2. (A) Degree of hydrolysis (\%) of the hydrolyzates from Erythrina edulis (pajuro) seed-derived albumin, globulin, and glutelin fractions after the action of pepsin for $30 \mathrm{~min}(\mathrm{PH})$, pepsin $30 \mathrm{~min}$ + pancreatin $60 \mathrm{~min}(\mathrm{PPH})$, and pepsin $30 \mathrm{~min}$ + pancreatin $60 \mathrm{~min}+$ Alcalase at different times (PPHA15, PPHA30, PPHA60, and PPH120). (B) SDS-PAGE analysis of (1) Erythrina edulis (pajuro) seed albumin fraction; (2) hydrolyzate by pepsin for $30 \mathrm{~min}(\mathrm{PH})$; (3) hydrolyzate by pepsin for $30 \mathrm{~min}$ and pancreatin for $60 \mathrm{~min}(\mathrm{PPH})$; (4) hydrolyzate by pepsin for $30 \mathrm{~min}$, pancreatin for $60 \mathrm{~min}$, and Alcalase for $15 \mathrm{~min}$ (PPHA15); (5) hydrolyzate by pepsin for $30 \mathrm{~min}$, pancreatin for $60 \mathrm{~min}$, and Alcalase for $30 \mathrm{~min}$ (PPHA30); (6) hydrolyzate by pepsin for $30 \mathrm{~min}$, pancreatin for $60 \mathrm{~min}$, and Alcalase for $60 \mathrm{~min}$ (PPHA60); (7) hydrolyzate by pepsin for $30 \mathrm{~min}$, pancreatin for $60 \mathrm{~min}$, and Alcalase for $120 \mathrm{~min}$ (PPHA120). MW: molecular weight marker SeeBlue ${ }^{\mathrm{TM}}$ Plus2 Prestained.

Moreover, the DH of glutelin PPH was higher to that described for the kanihuaderived glutelin fraction hydrolyzed for $2 \mathrm{~h}$ with both digestive enzymes (15.0\%) [28], although it was lower than that reported by Zhan et al. for sacha-inchi-derived glutelin 
hydrolyzed for $6 \mathrm{~h}$ with pepsin + pancreatin (28.6\%) [32]. The differences observed could be due to the conditions of the enzymatic reaction and the characteristics of the protein source.

The PPHs were subjected to further hydrolysis with Alcalase, observing a gradual increase of DH with incubation time, reaching values of $55.23,32.94$, and $37.82 \%$ at the end of hydrolysis of albumin, globulin, and glutelin, respectively. The observed differences could be due to the protease specificity of Alcalase and the protein source [33]. The highest increase in $\mathrm{DH}$ was observed in the albumin fraction, indicating the higher susceptibility of this protein to the enzymatic action. The broad specificity of Alcalase has been demonstrated, thus it is known that this microbial enzyme hydrolyzes most peptide bonds, releasing peptides with hydrophobic (Trp, Leu, Ile, Val, and Met) and aromatic (Phe and Tyr) amino acids [34]. The higher content of these amino acids in the albumin fraction (Table 1) could be responsible for its higher susceptibility to the microbial enzyme in comparison with globulin and glutelin fractions. Proteins from other plant species have also been found to be susceptible to Alcalase hydrolysis. Thus, protein from Vigna unguiculata was partially hydrolyzed by this microbial enzyme, reaching a DH value of $53.0 \%$ after 90 min of incubation [35]. Similarly, globulins and albumins from eight chickpea (Cicer arietinum L.) genotypes were found to be susceptible to Alcalase, and hydrolyzates obtained after 90 min showed DH values between 33.8 and 42.6\% [36]. The susceptibility of albumin to enzymatic hydrolysis was confirmed using a SDS-PAGE analysis. As shown in Figure 2B, the intensity of all bands visible in the non-hydrolyzed sample gradually decreased over the course of hydrolysis. Even bands of 58 and $25 \mathrm{kDa}$ disappeared after the action of pepsin for $30 \mathrm{~min}$. Only the band of $20 \mathrm{kDa}$ remained partially intact at the end of the hydrolytic process, indicating the partial resistance of this protein to the action of both digestive and microbial enzymes.

\subsection{Antioxidant Activity of Pajuro Protein Fractions}

Currently, the use of more than one method to evaluate the antioxidant activity of a compound is recommended. Thus, two biochemical assays (ABTS and ORAC) were selected to measure the $\mathrm{ABTS}^{\bullet+}$ and peroxyl radical scavenging capacity, respectively, of different hydrolyzates obtained from pajuro protein fractions (Figure 3A,B). Although intact protein fractions showed a slight radical scavenging capacity, their sequential proteolysis considerably increased it. The ABTS assay quantifies the suppressive capacity of an antioxidant against the $\mathrm{ABTS}^{\bullet+}$ radical. When added to medium containing this radical, the peptides released during hydrolysis act as electron donors, converting this radical cation into the non-radical ABTS. As shown in Figure 3A,C,E, proteolysis of pajuro protein fractions increased $\mathrm{ABTS}^{\bullet+}$ radical scavenging activity between 2- and 7-times, compared with non-hydrolyzed fractions. Albumin and globulin hydrolyzates obtained at the end of complete hydrolytic process showed the highest TEAC values $(1.37 \mu \mathrm{mol} \mathrm{TE} / \mathrm{mg}$ of albumin and $1.34 \mu \mathrm{mol} \mathrm{TE} / \mathrm{mg}$ of globulin), without differences between both fractions. These values were higher than those previously determined in the hydrolyzate of pajuro protein concentrate with Alcalase [13]. The higher ABTS ${ }^{\bullet+}$ radical scavenging capacity of the hydrolyzates obtained after the combined action of three enzymes (pepsin, pancreatin, and Alcalase) in comparison with those obtained only by pepsin could be due to the higher efficiency of the hydrolytic process. Thus, Chirinos et al. reported the higher antioxidant activity of Alcalase-Flavourzyme hydrolyzates from tarwi (Lupinus mutabilis) than that of Alcalase hydrolyzates [37]. Similarly, other works have found higher ABTS ${ }^{\bullet+}$ radical scavenging capacity of soybean [38], cañihua (Chenopodium pallidicaule) [39], and kiwicha (Amaranthus caudatus) [40] protein hydrolyzates using Alcalase combinations with other enzymes compared with only Alcalase. 
(A)

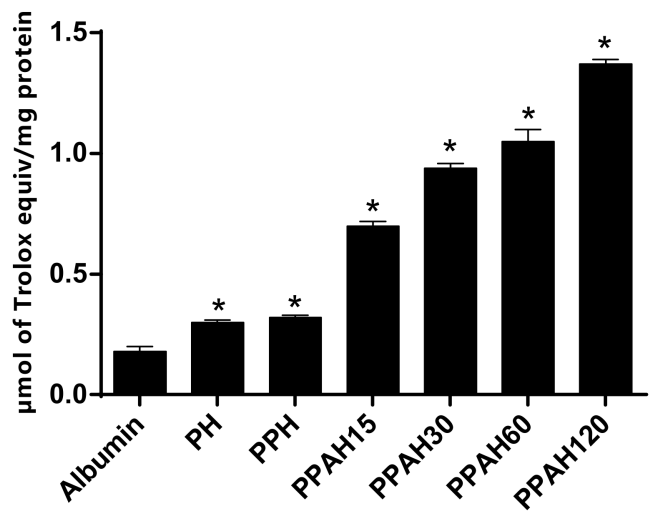

(C)

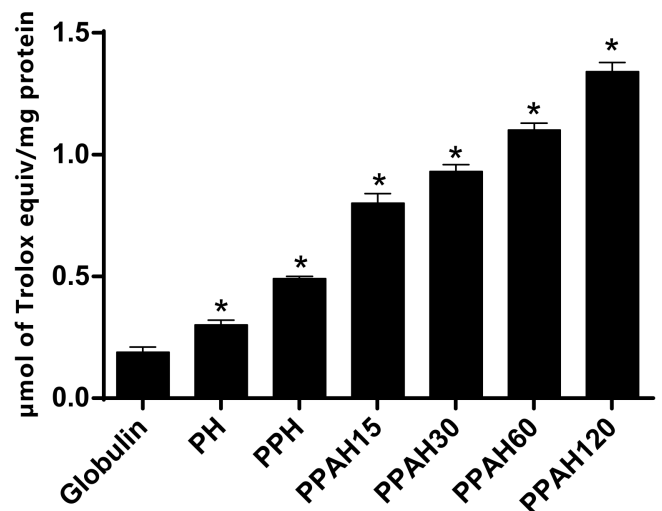

(E)

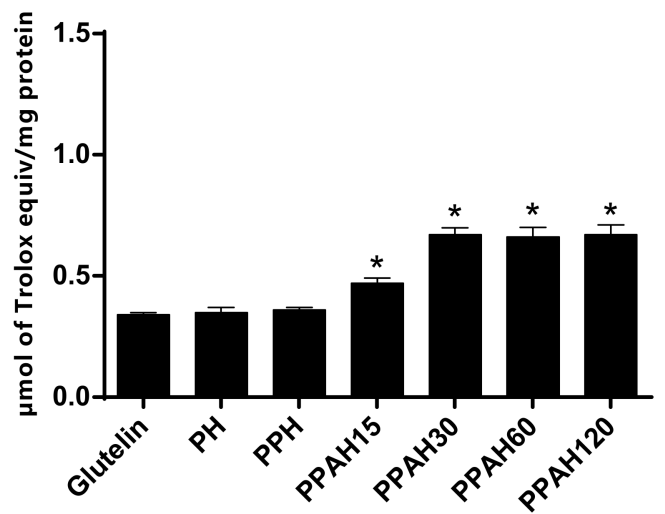

(B)

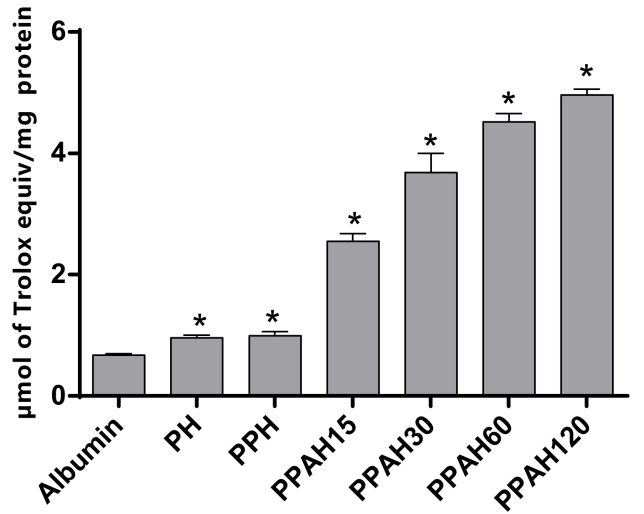

(D)

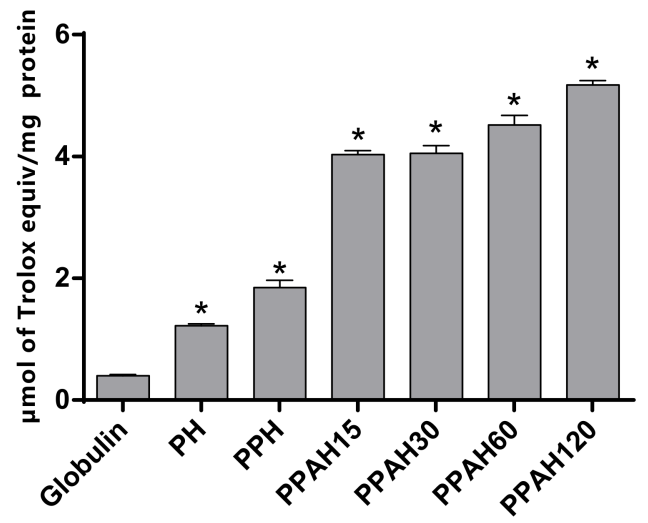

(F)

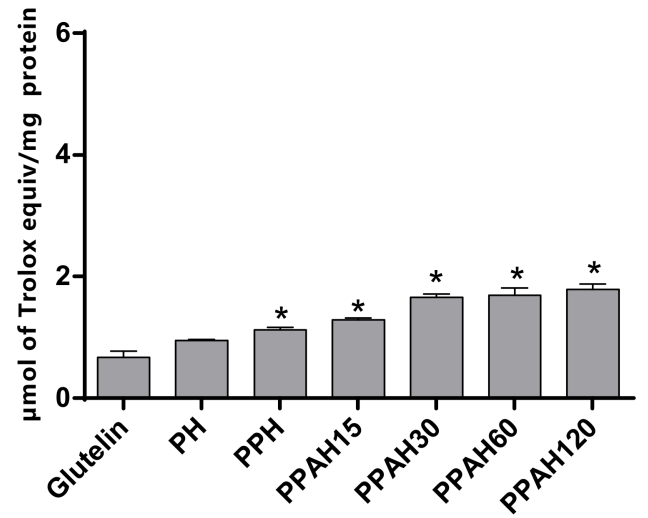

Figure 3. $\mathrm{ABTS}^{\bullet+}(\mathbf{A}, \mathbf{C}, \mathbf{E})$ and peroxyl $(\mathbf{B}, \mathbf{D}, \mathbf{F})$ radical scavenging capacity (expressed as $\mu \mathrm{mol}$ Trolox equivalents $/ \mathrm{mg}$ of protein) of hydrolyzates from (A,B) albumin, (C,D) globulin, and (E,F) glutelin with pepsin (PH), pepsin + pancreatin (PPH), and pepsin + pancreatin + alcalase for $15 \mathrm{~min}$ (PPHA15), $30 \mathrm{~min}$ (PPHA30), $60 \mathrm{~min}$ (PPHA60) and $120 \mathrm{~min}$ (PPHA120). ${ }^{*} p>0.05$ vs. protein fraction.

ORAC assay measures the ability of an antioxidant compound to break the chain reactions of thermally peroxyl radicals produced from AAPH. It is considered as one of the best methods for routine in vitro antioxidant capacity analysis of dietary supplements and food compounds, which combines peroxide radicals with physiological conditions, and has a wide application potential [41]. Pepsin hydrolyzates of pajuro protein fractions showed moderate ORAC values between 0.95 and $1.22 \mu \mathrm{mol} \mathrm{TE} / \mathrm{mg}$ of protein (Figure 3B,D,F).

After the sequential hydrolysis by pepsin and pancreatin, the antioxidant activity slightly increased in the albumin and glutelin hydrolyzates while the increase was more notable in the globulin hydrolyzate. Newly, the combined action of digestive and microbial enzymes resulted in hydrolyzates with potent peroxyl radicals scavenging capacity, obtaining ORAC values of $1.79,4.96$, and $5.18 \mu \mathrm{mol} \mathrm{TE} / \mathrm{mg}$ of protein for glutelin, albumin, and globulin fractions, respectively. The highest values corresponded to albumin and globulinderived hydrolyzates content in antioxidant amino acids (Tyr, Phe, Pro, Ala, His, Asp, Leu 
and Met), which are capable of acting as effective proton/hydrogen donors [42] representing $47 \%$ of TAA, suggesting the potential contribution of these residues on the antioxidant activity shown by the hydrolyzates. Albumin hydrolyzates from mung bean (Vigna radiata) have also been recently reported as a potent source of antioxidant peptides [43].

\subsection{In Vitro Anti-Hypertensive and Anti-Diabetic Activity of Pajuro Albumin Hydrolyzates}

Because of the high antioxidant activity demonstrated by albumin-derived hydrolyzates, they were selected to evaluate their multifunctionality. Firstly, the anti-hypertensive and anti-diabetic effects were evaluated in vitro through inhibition of ACE, $\alpha$-amylase, $\alpha$ glucosidase, DPP-IV, and pancreatic lipase activities (Table 2).

Table 2. In vitro anti-hypertensive and anti-diabetic activities of pajuro albumin-derived hydrolyzates obtained by hydrolysis with pepsin $(\mathrm{PH})$, hydrolysis with pepsin and pancreatin $(\mathrm{PPH})$, and hydrolysis with pepsin, pancreatin, and Alcalase for $15 \mathrm{~min}$ (PPHA15), $30 \mathrm{~min}$ (PPHA30), $60 \mathrm{~min}$ (PPHA60) and $120 \mathrm{~min}$ (PPHA120).

\begin{tabular}{|c|c|c|c|c|c|}
\hline Sample & $\begin{array}{c}\text { ACE } \\
\text { Inhibition (\%) }\end{array}$ & $\begin{array}{c}\alpha \text {-Amylase } \\
\text { Inhibition }(\%)\end{array}$ & $\begin{array}{c}\alpha \text {-Glucosidase } \\
\text { Inhibition }(\%) b\end{array}$ & $\begin{array}{c}\text { DPP-IV } \\
\text { Inhibition (\%) }^{c}\end{array}$ & $\begin{array}{l}\text { Pancreatic Lipase } \\
\text { Inhibition (\%) }\end{array}$ \\
\hline Albumin & $0.10 \pm 0.04$ & $22.80 \pm 6.85$ & $1.61 \pm 0.18$ & $2.31 \pm 1.48$ & n.d. \\
\hline Albumin PH & $13.45 \pm 1.88$ * & n.d. & n.d. & $16.16 \pm 1.48$ * & n.d. \\
\hline Albumin PPH & $20.85 \pm 1.06$ * & n.d. & n.d. & $35.73 \pm 1.35$ * & n.d. \\
\hline Albumin PPHA15 & $76.75 \pm 4.48^{* *}$ & n.d. & n.d. & $60.69 \pm 6.70^{* *}$ & n.d. \\
\hline Albumin PPHA30 & $64.20 \pm 6.15^{* *}$ & n.d. & n.d. & $58.19 \pm 3.13^{* *}$ & n.d. \\
\hline Albumin PPHA60 & $82.22 \pm 5.51^{* *}$ & n.d. & n.d. & $58.61 \pm 9.51^{* *}$ & n.d. \\
\hline Albumin PPHA120 & $83.60 \pm 0.09 * *$ & $14.60 \pm 1.32$ & $6.06 \pm 1.61$ & $64.81 \pm 5.31^{* *}$ & n.d. \\
\hline Positive control & $6.81 \pm 0.04$ & $87.44 \pm 1.61$ & $70.21 \pm 0.47$ & $0.86 \pm 0.01$ & $65.92 \pm 2.83$ \\
\hline
\end{tabular}

${ }^{a}$ : the percentage of ACE inhibition was determined at $100 \mu \mathrm{g}$ protein $/ \mathrm{mL} ;{ }^{\mathrm{b}}$ : the percentage of $\alpha$-amylase, $\alpha$-glucosidase, and pancreatic lipase inhibition was determined at protein concentration of $150 \mu \mathrm{g}$ protein $/ \mathrm{mL}{ }^{c}{ }^{c}$ : the percentage of DPP-IV inhibition was determined at protein concentration of $300 \mu \mathrm{g}$ protein $/ \mathrm{mL}$. Positive Controls: Captopril for ACE inhibition (IC 50 ); acarbose for $\alpha$-amylase and $\alpha$-glucosidase activity (\% inhibition at $10 \mathrm{mM}$ ); sitagliptin for DPP-IV inhibition $\left(\mathrm{IC}_{50}\right)$; orlistat for pancreatic lipase inhibition (\% inhibition at $0.5 \mu \mathrm{M}) .{ }^{*} p<0.05$ or ${ }^{* *} p<0.001 \mathrm{vs}$. albumin. The values corresponded to the mean of three replicates.

ACE is an enzyme that catalyzes the degradation of angiotensin I to produce angiotensin II with potent vasoconstrictor activity, and the cleavage of vasodilator bradykinin, thus promoting the increase of the blood pressure [44]. Thus, ACE inhibitory peptides are considered as a useful strategy for preventing hypertension. As observed in Table 2, the intact albumin fraction did not show any inhibitory effect on ACE. However, after its sequential hydrolysis by digestive and microbial enzymes, the inhibitory capacity gradually increased, reaching $83.60 \%$ inhibition when albumin-PPHA120 was analyzed at $100 \mu \mathrm{g}$ protein $/ \mathrm{mL}$. The $\mathrm{IC}_{50}$ calculated for this hydrolyzate was $50.65 \mu \mathrm{g}$ protein $/ \mathrm{mL}$. Although this value was higher than that measured for Captopril, used as standard in this assay $(6.81 \mu \mathrm{g} / \mathrm{mL})$, it was much lower than those reported for hydrolyzates from other plant proteins. As examples, Alcalase-hydrolyzates of Lupinus angustifolius protein showed $\mathrm{IC}_{50}$ values ranged from 100-210 $\mu \mathrm{g}$ protein/mL [45], and the tarwi protein hydrolyzate by an Alcalase-Neutrase combination for $180 \mathrm{~min}$ showed an $\mathrm{IC}_{50}$ value of $110 \mu \mathrm{g}$ protein/mL [37].

The antidiabetic activity of albumin-derived hydrolyzates was determined by evaluating the inhibition of metabolic enzymes $\alpha$-amylase, $\alpha$-glucosidase, and DPP-IV. $\alpha$-amylase and $\alpha$-glucosidase are the primary enzymes implied in the digestion of dietary starch, releasing oligosaccharides that can be further broken down into glucose, which is rapidly absorbed by the body. Therefore, blocking these enzymes results in a reduced absorption rate of sugars and helps to manage both body weight and blood sugars [46]. Undigested albumin at concentration of $150 \mu \mathrm{g}$ protein $/ \mathrm{mL}$ inhibited $22.80 \% \alpha$-amylase, without showing any effects on the rest of enzymes. Acarbose, used as standard in the $\alpha$-amylase and $\alpha$-glucosidase inhibition assays, showed $87.44 \%$ and $70.21 \%$ inhibition, respectively, at concentrations of $10 \mathrm{mM}$. Once completely hydrolyzed, the final digest showed slight inhibitory effects on $\alpha$-amylase and $\alpha$-glucosidase that could be due to the low protein concentration assayed $(150 \mu \mathrm{g}$ protein $/ \mathrm{mL})$. On the contrary, other studies have reported 
higher inhibition rates at higher concentrations of protein. Thus, incubation of $225 \mu \mathrm{g}$ protein $/ \mathrm{mL}$ of yellow field pea (Pisum sativum L.) protein hydrolyzates with $\alpha$-amylase resulted in $\approx 31 \%$ inhibition of the enzyme while a concentration of $20 \mathrm{mg} / \mathrm{mL}$ was needed to inhibit $53.4 \%$ of $\alpha$-glucosidase activity [47]. Mojica and de Mejia reported $53.4 \% \alpha$ amylase inhibition for Alcalase hydrolyzate of black bean proteins at a final concentration of $330 \mathrm{mg}$ hydrolyzate/ $\mathrm{mL}$ [48]. In the case of $\alpha$-glucosidase inhibitory activity, gastrointestinal digests from quinoa protein showed and $\mathrm{IC}_{50}$ value of $1.81 \mathrm{mg}$ protein $/ \mathrm{mL}$ [49], and Alcalase hemp seed proteins hydrolyzates reached $50 \%$ enzyme inhibition at concentrations higher than $5 \mathrm{mg} / \mathrm{mL}$ [50]. A recent study reported inhibitory values of $38.9 \%$ ( $\alpha$-amylase) and $48.8 \%$ ( $\alpha$-glucosidase) for eggplant leaf protein hydrolyzates at $500 \mu \mathrm{g}$ hydrolyzate/mL [51].

In contrast to the moderate effects observed on $\alpha$-amylase and $\alpha$-glucosidase, the pajuro albumin hydrolyzates showed potent inhibitory effects on DPP-IV. This enzyme is responsible for degradation and inactivation of gut incretin hormones that act after food ingestion by stimulating glucose-dependent insulin secretion in the pancreatic $\beta$ cells [52,53]. Specific DPP-IV inhibition has been demonstrated to increase the half-life of circulating incretins, to reduce plasma glucose levels, and to improve glucose tolerance [54]. Undigested albumin (300 $\mu \mathrm{g}$ protein $/ \mathrm{mL}$ ) did not show any effects on DPP-IV. This result agrees previous studies that had reported null or weak inhibitory effects for intact proteins from plant and animal sources. Thus, intact walnut protein at $500 \mu \mathrm{g} / \mathrm{mL}$ showed DPP-IV inhibition rates lower than 5\% [55]. In another recent study, low DPP-IV inhibitory activity was also reported for undigested amaranth protein isolate as reflected by an $\mathrm{IC}_{50}$ value of $8.22 \mathrm{mg} / \mathrm{mL}$ [56]. Similarly, a previous study had reported low DPP-IV inhibitory effects for intact amaranth glutelins [57]. In this last study, inhibitory activity increased in a dose-dependent manner when glutelins were subjected to trypsin hydrolysis. In our study, the inhibitory effects on DPP-IV were hydrolysis-dependent, reaching 35.73\% inhibition after the action of digestive enzymes and $64.81 \%$ at the end of sequential hydrolysis (Table 2). The $\mathrm{IC}_{50}$ value calculated by albumin-PPHA120 was $230.57 \mu \mathrm{g}$ protein $/ \mathrm{mL}$. This value was similar to that reported for gastrointestinal digests from quinoa protein $(250 \mu \mathrm{g}$ protein $/ \mathrm{mL})$ [49] and higher than that reported by for walnut protein hydrolyzates by Alcalase $(900 \mu \mathrm{g} / \mathrm{mL})$ [55]. The differences found among studies could be due to the protein source and the type of enzymes involved in the hydrolysis [58,59].

Since pancreatic lipase is a crucial enzyme involved in the intestinal digestion of dietary triacylglycerols, a major source of excess calorie intake, its inhibition results in reduction of fat digestion and absorption, and consequently in moderate long-term reductions in body weight [60]. Therefore, lipase inhibitors are considered as useful in the management of obesity [61]. In our study, no inhibitory effects were observed for both undigested and digested pajuro albumins that could be due to the low concentration assayed $(150 \mu \mathrm{g}$ protein $/ \mathrm{mL})$. Previous studies have reported inhibitory effects on this enzyme at much higher doses. Thus, the $\mathrm{IC}_{50}$ value reported for Alcalase hydrolyzates from pea protein was $3.98 \mathrm{mg} / \mathrm{mL}$ [47], and values determined in black bean proteins hydrolyzates with pepsin/pancreatin or alcalase were 3.21 and $1.23 \mathrm{mg} / \mathrm{mL}$, respectively [62].

\subsection{Neuroprotective Effects of Pajuro Albumin Hydrolyzates}

Because of the limitations associated with the use of synthetic compounds against neurodegenerative disorders, the interest has focused on naturally derived compounds with potential neuroprotective properties [63]. Thus, we aimed to evaluate the neuroprotective effects of pajuro albumin hydrolyzates against $\mathrm{FeSO}_{4}$-induced neurotoxicity in the SH-SY5Y cell line. In our study, these hydrolyzates have been demonstrated to scavenge radicals in both ABTS and ORAC assays (Figure 3). The excessive production of free radicals in the brain together the accumulation of transition metals has been reported to contribute on the neuronal cell death [64]. Therefore, scavenging free radicals could inhibit neurodegenerative diseases [65]. Firstly, MTT analysis was performed to evaluate the cytotoxicity of the albumin hydrolyzates against neuroblastoma SH-SY5Y cells under basal 
conditions at doses ranged from 0.25 to $2 \mathrm{mg} / \mathrm{mL}$. As shown in Figure $4 \mathrm{~A}$, the highest dose $(2 \mathrm{mg} / \mathrm{mL})$ of the albumin-PPHA120 did not affect the cell viability. However, lower doses resulted in a significant increase of the viability reaching $161.41 \%$ viable cells (compared with non-treated cells) when cells were treated with $0.25 \mathrm{mg} / \mathrm{mL}$ of the hydrolyzate.
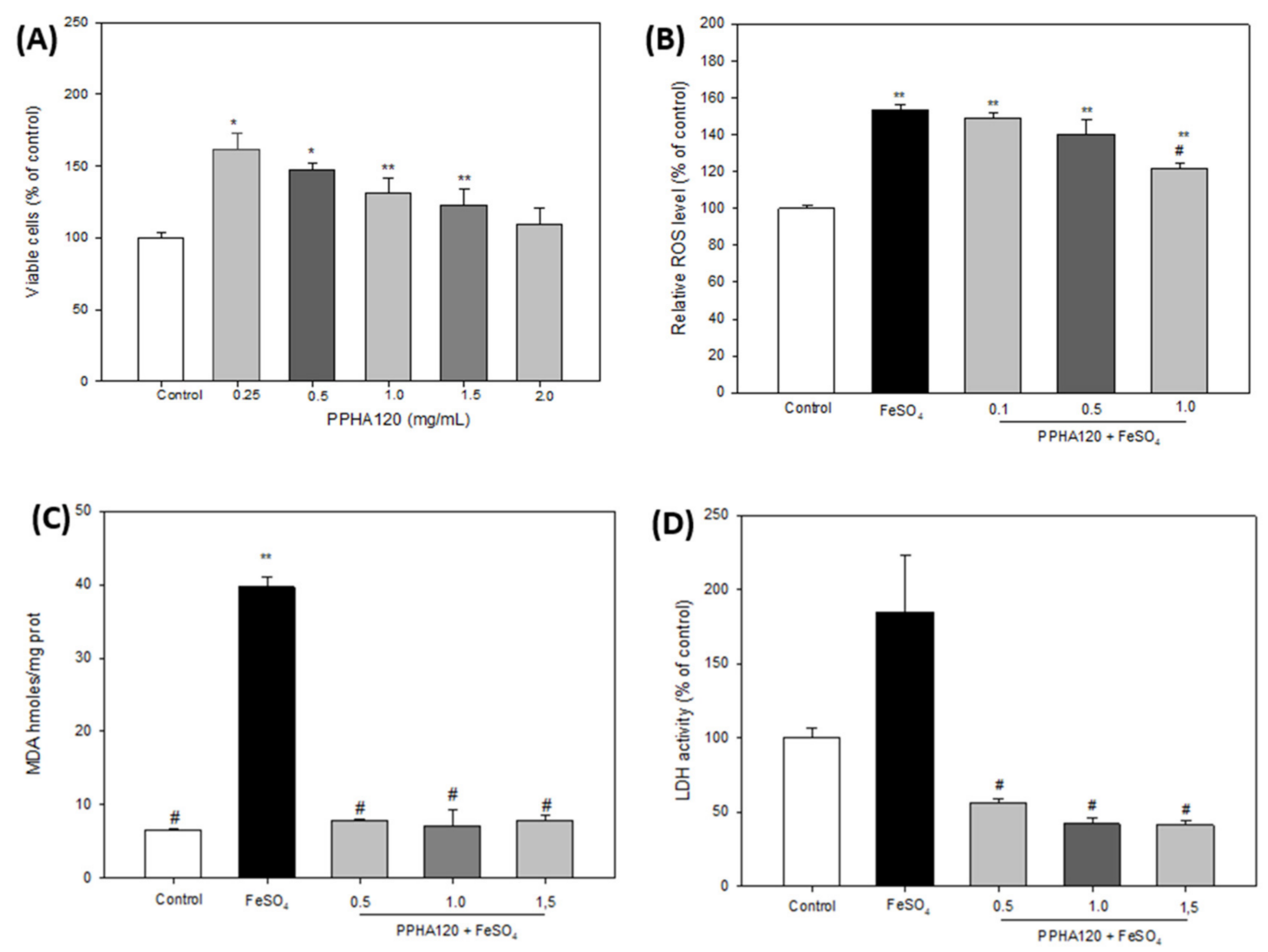

Figure 4. (A) Viable SH-SY5Y cells (\% of control) after their treatment with the pajuro albumin hydrolyzate PPHA120 at different concentrations $\left(0.25-2 \mathrm{mg} / \mathrm{mL}\right.$ ). (B) ROS levels (\% of control) after the treatment of SH-SY5Y cells with FeSO $\mathrm{F}_{4}$ in the absence and presence of PPHA120 at different concentrations (0.1-1.0 mg/mL). (C) MDA levels (nmoles/mg protein) after the treatment of SH-SY5Y cells with $\mathrm{FeSO}_{4}$ in the absence and presence of PPHA120 at different concentrations $(0.5-1.5 \mathrm{mg} / \mathrm{mL})$. (D) LDH activity (\% of control) after the treatment of SH-SY5Y cells with $\mathrm{FeSO}_{4}$ in the absence and presence of PPHA120 at different concentrations $(0.5-1.5 \mathrm{mg} / \mathrm{mL}) .{ }^{*} p<0.05$ or ${ }^{* *} p<0.001$ vs. control (non-treated cells), $\# p<0.001$ vs. $\mathrm{FeSO}_{4}$-treated cells.

Oxidative damage induces increase of intracellular ROS, which leads to cell death [66]. Therefore, we investigated the protective effects of the albumin hydrolyzate against the oxidative damage induced by $\mathrm{FeSO}_{4}$ through quantification of the intracellular ROS levels using fluorescence with DCFA-DH (Figure 4B). In this assay, concentrations of 0.25, 0.5, and $1 \mathrm{mg} / \mathrm{mL}$ of albumin-PPHA120 were used. $\mathrm{FeSO}_{4}$ stimulation resulted in a significant increase of ROS levels up to $153.31 \%$ (compared to non-induced cells). However, treatment of induced cells with the hydrolyzate reverted the oxidative damage in a dose-dependent manner although the ROS levels quantified at the highest concentration assayed were still above control (121.58\%). Although the data are still limited, some food-derived hydrolyzates have also been found to decrease ROS levels in injured nerve cells. Thus, Sheng et al. reported protective effects of defatted walnut (Juglans regia L.) meal hydrolyzate against oxidative damage induced by $\mathrm{H}_{2} \mathrm{O}_{2}$ in $\mathrm{SH}-\mathrm{SY} 5 \mathrm{Y}$ cells [67]. A peptide (SGGY) identified in the walnut protein after simulating its gastrointestinal digestion was also demonstrated to exert effective protection in this cell model [68]. Similarly, Lee \& Hur demonstrated that peptide fractions derived from beef protein hydrolyzates with alkalineAK and papain decreased ROS levels compared to $\mathrm{H}_{2} \mathrm{O}_{2}$-treated SH-SY5Y cells [69]. Next, 
these authors extracted the $<3 \mathrm{kDa}$ fraction from the alkaline-AK hydrolyzate and evaluated their protective effects on induced neuronal cells through other mechanisms of action [70]. They demonstrated the neuroprotective effects of the fraction by increasing cell viability, inhibiting nitric oxide production and fragmentation of cell nuclei, increasing the mitochondrial membrane potential, and reducing apoptosis. In addition to the effects on ROS generation, we aimed at evaluating the effects of the albumin hydrolyzate through other mechanisms. Thus, their effects on lipidic peroxidation and LDH levels were investigated. As shown in Figure 4C, cell induction with $\mathrm{FeSO}_{4}$ resulted in a significant increase of MDA levels that was reverted by the albumin-PPHA120 at all assayed concentrations. $\mathrm{LDH}$ is considered an important index to detect cell death because it is released into the culture medium when the cell membrane is damaged [71]. In our study, we found that the level of LDH was significantly increased in $\mathrm{FeSO}_{4}$-induced cells (184.65\% compared to non-induced cells), while treatment with the hydrolyzate the LDH levels in the supernatant were all significantly reduced in SH-SY5Y cells, reaching values lower than that of control cells $(42.16 \%$ at dose of $1.0 \mathrm{mg} / \mathrm{mL}$ ) (Figure $4 \mathrm{D}$ ).

\section{Conclusions}

In the present study, albumin, globulin, glutelin, and prolamin fractions were separated from E. edulis flour and hydrolyzed by a sequential process with digestive and microbial enzymes. Among hydrolyzates produced by the combined action of pepsin, pancreatin, and Alcalase on albumin fraction showed potent radical scavenging and ACE inhibitory activity, and anti-diabetic properties through inhibition of $\alpha$-amylase, $\alpha$-glucosidase, and DPP-IV enzymes. It also exerted a notable neuroprotective effect in a neuroblastoma cell model induced by $\mathrm{FeSO}_{4}$ through modulation of oxidative stress-associated biomarkers. These findings point pajuro albumin out as a promising source of multifunctional peptides with high value in the formulation of functional foods and/or nutraceuticals for health promotion and prevention of chronic disorders associated to oxidative stress, hypertension, and metabolic alterations. Further research would be needed to isolate and identify the peptides responsible for the observed effects and confirm their bioavailability and bioactivity.

Author Contributions: C.P.-A. and A.I. performed the experiments and analyzed the data; K.J.-A., conceptualization, conceived the experiments, writing—original draft preparation, funding acquisition; N.R.-A. and E.S., methodology; E.F. contributed the reagents and materials, validation, project administration; A.I.Z., conceptualization, formal analysis, funding acquisition; V.I. contributed with reagents and materials, formal analysis, data curation; B.H.-L., conceived the experiments, analyzed the data, and wrote the paper. All authors have read and agreed to the published version of the manuscript.

Funding: This work has received financial support from project CONCYTEC-Banco Mundial "Mejoramiento y Ampliación de los Servicios del Sistema Nacional de Ciencia Tecnología e Innovación Tecnológica" 8682-PE, through its executing unit ProCiencia (Contrato 042-2018-FONDECYT-BMIADT-AV) and from the Universidad Nacional Mayor de San Marcos (RR N ${ }^{\circ}$ 01686-R-20, project A20040171).

Institutional Review Board Statement: Not applicable.

Informed Consent Statement: Not applicable.

Data Availability Statement: Data is contained within the article.

Conflicts of Interest: The authors declare no conflict of interest.

\section{References}

1. Pihlanto, A.; Mattila, P.; Mäkinena, S.; Pajari, A.-M. Bioactivities of alternative protein sources and their potential health benefits. Food Funct. 2017, 8, 3443-3458. [CrossRef] [PubMed]

2. Rutherfurd-Markwick, K.J. Food proteins as a source of bioactive peptides with diverse functions. Br. J. Nutr. 2012, 108, S149-S157. [CrossRef] 
3. Chelliah, R.; Wei, S.; Daliri, E.; Elahi, F.; Yeon, S.-J.; Tyagi, A.; Liu, S.; Madar, I.H.; Sultan, G.; Oh, D.-H. The role of bioactive peptides in diabetes and obesity. Foods 2021, 10, 2220. [CrossRef] [PubMed]

4. Daroit, D.J.; Brandelli, A. In vivo bioactivities of food protein-derived peptides-A current review. Curr. Opin. Food Sci. 2021, 39, 120-129. [CrossRef]

5. Shobako, N. Hypotensive peptides derived from plant proteins. Peptides 2021, 142, 170573. [CrossRef]

6. Nongonierma, A.B.; FitzGerald, R.J. Strategies for the discovery and identification of food protein-derived biologically active peptides. Trends Food Sci. Technol. 2017, 69, 289-305. [CrossRef]

7. Olivieri, C. The current state of heart disease: Statins, cholesterol, fat and sugar. Int. J. Evid. Based Healthc. 2019, 17, 179-186. [CrossRef]

8. Ghaedi, E.; Mohammadi, M.; Mohammadi, H.; Ramezani-Jolfaie, N.; Malekzadeh, J.; Hosseinzadeh, M.; Salehi-Abargouei, A. Effects of a paleolithic diet on cardiovascular disease risk factors: A systematic review and meta-analysis of randomized controlled trials. Adv. Nutr. 2019, 10, 634-646. [CrossRef]

9. Pontes Oliveira de Almeida, A.S.; Silva de Almeida Rezende, M.; Dantas, S.H.; de Lima Silva, S.; Pinheiro Lúcio de Oliveira, J.C.; Araújo de Azevedo, F.L.A.; Ribeiro Alves, R.M.F.; Sales de Menezes, G.M.; Ferreira dos Santos, P.; Felisberto Gonçalves, T.A.; et al. Unveiling the role of inflammation and oxidative stress on age-related cardiovascular diseases. Oxid. Med. Cell. Longev. 2020, 2020, 1954398. [CrossRef]

10. Daliri, E.B.; Oh, D.H.; Lee, B.H. Bioactive peptides. Foods 2017, 6, 32. [CrossRef]

11. Lammi, C.; Aiello, G.; Boschin, G.; Arnoldi, A. Multifunctional peptides for the prevention of cardiovascular disease: A new concept in the area of bioactive food-derived peptides. J. Funct. Foods 2019, 55, 135-145. [CrossRef]

12. Arango Bedoya, O.; Bolaños Patiño, V.; Ricaurte García, D.; Caicedo, M.; Guerrero, Y. Obtaining a protein extract from chachafruto flour (Erythrina edulis). Rev. Univ. Salud 2012, 14, 161-167.

13. Intiquilla, I.; Jiménez-Aliaga, K.; Zavaleta, A.I.; Arnao, I.; Peña, C.; Chávez-Hidalgo, E.L.; Hernández-Ledesma, B. Erythrina edulis (pajuro) seed protein: A new source of antioxidant peptides. Nat. Prod. Commun. 2016, 11, 1934578X1601100620. [CrossRef]

14. Sánchez Chero, M.J.; Sánchez Chero, J.A.; Miranda Zamora, W. Technify and conserve the bioactive components of Pashul (Erythrina edulis) for human consumption. UCV HACER Rev. Inv. Cult. 2019, 8, 11-17.

15. Intiquilla, A.; Jiménez-Aliaga, K.; Guzmán, F.; Álvarez, C.A.; Zavaleta, A.I.; Izaguirre, V.; Hernández-Ledesma, B. Novel antioxidant peptides obtained by alcalase hydrolysis of Erythrina edulis (pajuro) protein. J. Sci. Food Agric. 2019, 99, $2420-2427$. [CrossRef]

16. Chavan, U.D.; McKenzie, D.B.; Shahidi, F. Functional properties of protein isolates from beach pea (Lathyrus maritimus L.). Food Chem. 2001, 74, 177-187. [CrossRef]

17. Nielsen, P.M.; Petersen, D.; Dambmann, C. Improved method for determining food protein degree of hydrolysis. J. Food Sci. 2001, 66, 642-646. [CrossRef]

18. Re, R.; Pellergrini, N.; Proteggente, A.; Pannala, A.; Yang, M.; Rice-Evans, C. Antioxidant activity applying an improved ABTS radical. Free Radic. Biol. Med. 1999, 26, 1231-1237. [CrossRef]

19. Hernández-Ledesma, B.; Dávalos, A.; Bartolomé, B.; Amigo, L. Preparation of antioxidant enzymatic hydrolysates from $\alpha$ lactalbumin and $\beta$-lactoglobulin. Identification of active peptides by HPLC-MS/MS. J. Agric. Food Chem. 2005, 53, 588-593. [CrossRef] [PubMed]

20. Hayakari, M.; Kondo, Y.; Izumi, H. A rapid and simple spectrophotometric assay of angiotensin-converting enzyme. Anal. Biochem. 1978, 84, 361-369. [CrossRef]

21. Subramanian, R.; Asmawi, M.Z.; Sadikun, A. In vitro $\alpha$-glucosidase and $\alpha$-amylase enzyme inhibitory effects of Andrographis paniculata extract and andrographolide. Acta Biochim. Pol. 2008, 55, 391-398. [CrossRef]

22. Kumar Singla, R.; Singh, R.; Kumar Dubey, A. Important aspects of post-prandial antidiabetic drug, acarbose. Curr. Top. Med. Chem. 2016, 16, 2625-2633. [CrossRef]

23. Johnson, M.; Lucius, A.; Meyer, T.; De Mejia, E. Cultivar evaluation and effect of fermentation on antioxidant capacity and in vitro inhibition of alpha-amylase and alpha-glucosidase by highbush blueberry (Vaccinium corombosum). J. Agric. Food Chem. 2011, 59, 8923-8930. [CrossRef]

24. Liu, S.; Yu, Z.; Zhu, H.; Zhang, W.; Chen, Y. In vitro alpha-glucosidase inhibitory activity of isolated fractions from water extract of Qingzhuan dark tea. Bmc Complement. Altern. Med. 2016, 16, 378. [CrossRef] [PubMed]

25. Gupta, N.; Rathi, P.; Gupta, R. Simplified para-nitrophenyl palmitate assay for lipases and esterases. Anal. Biochem. 2002, 311, 98-99. [CrossRef]

26. Dolenc, A.; Govedarica, B.; Dreu, R.; Kocbek, P.; Srčič, S.; Kristl, J. Nanosized particles of orlistat with enhanced in vitro dissolution rate and lipase inhibition. Int. J. Pharm. 2010, 396, 149-155. [CrossRef] [PubMed]

27. LeBel, C.P.; Ischiropoulos, H.; Bondy, S.C. Evaluation of the probe $2^{\prime}, 7^{\prime}$-dichlorofluorescin as an indicator of reactive oxygen species formation and oxidative stress. Chem. Res. Toxicol. 1992, 5, 227-231. [CrossRef] [PubMed]

28. Rubio, L.A.; Pérez, A.; Ruiz, R.; Guzmán, M.A.; Aranda-Olmedo, I.; Clemente, A. Characterization of pea (Pisum sativum) seed protein fractions. J. Sci. Food Agric. 2014, 94, 280-287. [CrossRef]

29. Moscoso-Mujica, G.; Zavaleta, A.I.; Mujica, A.; Arnao, I.; Moscoso-Neira, C.; Santos, M.; Sánchez, J. Antimicrobial peptides purified from hydrolysates of kanihua (Chenopodium pallidicaule Aellen) seed protein fractions. Food Chem. 2021, $360,129951$. [CrossRef] 
30. Quist, E.E.; Phillips, R.D.; Saalia, F.K. The effect of enzyme systems and processing on the hydrolysis of peanut (Arachis hypogaea L.) protein. LWT Food Sci. Technol. 2009, 42, 1717-1721. [CrossRef]

31. Castañeda-Pérez, E.; Jiménez-Morales, K.; Castellanos-Ruelas, A.; Chel-Guerrero, L.; Betancur-Ancona, D. Antidiabetic potential of protein hydrolysates and peptide fractions from lima bean (Phaseolus lunatus L): An in vitro study. Int. J. Pept. Res. Ther. 2021, 27, 1979-1988. [CrossRef]

32. Zhan, Q.; Wang, Q.; Liu, Q.; Guo, Y.; Gong, F.; Hao, L.; Wu, H.; Dong, Z. The antioxidant activity of protein fractions from Sacha inchi seeds after a simulated gastrointestinal digestion. LWT Food Sci. Technol. 2021, 145, 111356. [CrossRef]

33. Doucet, D.; Otter, D.E.; Gauthier, S.F.; Foegeding, E.A. Enzyme-induced gelation of extensively hydrolyzed whey proteins by Alcalase: Peptide identification and determination of enzyme specificity. J. Agric. Food Chem. 2003, 51, 6300-6308. [CrossRef] [PubMed]

34. Balderas-León, I.; Baigts-Allende, D.; Cardador-Martínez, A. Antioxidant, angiotensin-converting enzyme, and $\alpha$-amylase inhibitory activities of protein hydrolysates of Leucaena leucocephala seeds. CyTA J. Food 2021, 19, 349-359. [CrossRef]

35. Segura Campos, M.R.; Chel Guerrero, L.A.; Betancur Ancona, D.A. Angiotensin-I converting enzyme inhibitory and antioxidant activities of peptide fractions extracted by ultrafiltration of cowpea Vigna unguiculata hydrolysates. J. Sci. Food Agric. 2010, 90, 2512-2518. [CrossRef]

36. Quintero-Soto, M.F.; Chávez-Ontiveros, J.; Garzón-Tiznado, J.A.; Salazar-Salas, N.Y.; Pineda-Hidalgo, K.V.; Delgado-Vargas, F.; López-Valenzuela, J.A. Characterization of peptides with antioxidant activity and antidiabetic potential obtained from chickpea (Cicer arietinum L.) protein hydrolyzates. J. Food Sci. 2021, 86, 2962-2977. [CrossRef]

37. Chirinos, R.; Cerna, E.; Pedreschi, R.; Calsin, M.; Aguilar-Galvez, A.; Campos, D. Multifunctional in vitro bioactive properties: Antioxidant, antidiabetic, and antihypertensive of protein hydrolyzates from tarwi (Lupinus mutabilis Sweet) obtained by enzymatic biotransformation. Cereal Chem. 2021, 98, 423-433. [CrossRef]

38. Chen, C.; Sun-Waterhouse, D.; Zhang, Y.; Zhao, M.; Sun, W. The chemistry behind the antioxidant actions of soy protein isolate hydrolysates in a liposomal system: Their performance in aqueous solutions and liposomes. Food Chem. 2020, 323, 126789. [CrossRef]

39. Chirinos, R.; Ochoa, K.; Aguilar-Galvez, A.; Carpentier, S.; Pedreschi, R.; Campos, D. Obtaining of peptides with in vitro antioxidant and angiotensin I converting enzyme inhibitory activities from cañihua protein (Chenopodium pallidicaule Aellen). J. Cereal Sci. 2018, 83, 139-146. [CrossRef]

40. Chirinos, R.; Pedreschi, R.; Velásquez-Sánchez, M.; Aguilar-Galvez, A.; Campos, D. In vitro antioxidant and angiotensin-I converting enzyme inhibitory properties of enzymatically hydrolysed quinoa (Chenopodium quinoa) and kiwicha (Amaranthus caudatus) proteins. Cereal Chem. 2020, 97, 949-957, In press. [CrossRef]

41. Jingbo, L.; Chen, Z.; He, J.; Zhang, Y.; Zhang, T.; Jiang, Y. Anti-oxidative and anti-apoptosis effects of egg white peptide, TrpAsn-Trp-Ala-Asp, against H2O2-induced oxidative stress in human embryonic kidney 293 cells. Food Funct. 2014, 5, 3179-3188. [CrossRef]

42. Wong, F.C.; Xiao, J.; Wang, S.; Ee, K.Y.; Chai, T.T. Advances on the antioxidant peptides from edible plant sources. Trends Food Sci. Technol. 2020, 99, 44-57. [CrossRef]

43. Kusumah, J.; Real Hernandez, L.M.; Gonzalez de Mejia, E. Antioxidant potential of mung bean (Vigna radiata) albumin peptides produced by enzymatic hydrolysis analyzed by biochemical and in silico methods. Foods 2020, 9, 1241. [CrossRef] [PubMed]

44. Tom, B.; Dendorfer, A.; Jan Danser, A.H. Bradykinin, angiotensin-(1-7), and ACE inhibitors: How do they interact? Int. J. Biochem. Cell Biol. 2003, 35, 792-801. [CrossRef]

45. Chin, Y.Y.; Chew, L.Y.; Toh, G.T.; Salampessy, J.; Azlan, A.; Ismail, A. Nutritional composition and angiotensin converting enzyme inhibitory activity of blue lupin (Lupinus angustifolius). Food Biosci. 2019, 31, 100401. [CrossRef]

46. Esfandi, R.; Seidu, I.; Willmore, W.; Tsopmo, A. Antioxidant, pancreatic lipase, and $\alpha$-amylase inhibitory properties of oat bran hydrolyzed proteins and peptides. J. Food Biochem. 2021, 00, e13762. [CrossRef]

47. Awosika, T.O.; Aluko, R.E. Inhibition of the in vitro activities of a-amylase, a-glucosidase and pancreatic lipase by yellow field pea (Pisum sativum L.) protein hydrolysates. Int. J. Food Sci. Technol. 2019, 54, 2021-2034. [CrossRef]

48. Mojica, L.; de Mejia, E.G. Optimization of enzymatic production of antidiabetic peptides from black bean (Phaseolus vulgaris L.) proteins, their characterization and biological potential. Food Funct. 2016, 7, 713-727. [CrossRef]

49. Vilcacundo, R.; Martínez-Villaluenga, C.; Hernández-Ledesma, B. Release of dipeptidyl peptidase IV, $\alpha$-amylase and $\alpha$-glucosidase inhibitory peptides from quinoa (Chenopodium quinoa Willd.) during in vitro simulated gastrointestinal digestion. J. Funct. Foods 2017, 35, 531-539. [CrossRef]

50. Ren, Y.; Liang, K.; Jin, Y.; Zhang, M.; Chen, Y.; Wu, H.; Lai, F. Identification and characterization of two novel a-glucosidase inhibitory oligopeptides from hemp (Cannabis sativa L.) seed protein. J. Funct. Foods 2016, 26, 439-450. [CrossRef]

51. Famuwagun, A.A.; Alashi, A.M.; Gbadamosi, S.O.; Taiwo, K.A.; Oyedele, D.; Adebooye, O.C.; Aluko, R.E. Effect of protease type and peptide size on the in vitro antioxidant, antihypertensive and anti-diabetic activities of eggplant leaf protein hydrolysates. Foods 2021, 10, 1112. [CrossRef]

52. Holst, J.J.; Deacon, C.F. Glucagon-like peptide 1 and inhibitors of dipeptidyl peptidase IV in the treatment of type 2 diabetes mellitus. Curr. Opin. Pharmacol. 2004, 4, 589-596. [CrossRef]

53. Mentlein, R. Therapeutic assessment of glucagon-like peptide- 1 agonists compared with dipeptidyl peptidase IV inhibitors as potential antidiabetic drugs. Expert Opin. Investig. Drugs 2005, 14, 57-64. [CrossRef] [PubMed] 
54. Mitani, H.; Takimoto, M.; Hughes, T.E.; Kimura, M. Dipeptidyl peptidase IV inhibition improves impaired glucose tolerance in high-fat diet-fed rats: Study using a Fischer 344 rat substrain deficient in its enzyme activity. Jpn. J. Pharmacol. 2002, 88, 442-450. [CrossRef]

55. Kong, X.; Zhang, L.; Song, W.; Zhang, C.; Hua, Y.; Chen, Y.; Li, X. Separation, identification and molecular binding mechanism of dipeptidyl peptidase IV inhibitory peptides derived from walnut (Juglans regia L.) protein. Food Chem. 2021, 347,129062 [CrossRef]

56. Kamal, H.; Mudgil, P.; Bhaskar, B.; Fisayo, A.F.; Gan, C.-Y.; Maqsood, S. Amaranth proteins as potential source of bioactive peptides with enhanced inhibition of enzymatic markers linked with hypertension and diabetes. J. Cereal Sci. 2021, 101, 103308. [CrossRef]

57. Velarde-Salcedo, A.J.; Barrera-Pacheco, A.; Lara-González, S.; Montero-Morán, G.M.; Díaz-Gois, A.; González de Mejia, E.; Barba de la Rosa, A. In vitro inhibition of dipeptidyl peptidase IV by peptides derived from the hydrolysis of amaranth (Amaranthus hypochondriacus L.) proteins. Food Chem. 2013, 136, 758-764. [CrossRef]

58. Wang, F.; Yu, G.; Zhang, Y.; Zhang, B.; Fan, J. Dipeptidyl peptidase IV inhibitory peptides derived from oat (Avena sativa L.), buckwheat (Fagopyrum esculentum), and highland barley (Hordeum vulgare trifurcatum (L.) Trofim) proteins. J. Agric. Food Chem. 2015, 63, 9543-9549. [CrossRef] [PubMed]

59. Zhang, Y.; Chen, R.; Chen, X.; Zeng, Z.; Ma, H.; Chen, S. Dipeptidyl peptidase IV-inhibitory peptides derived from silver carp (Hy-pophthalmichthys molitrix Val.) proteins. J. Agric. Food Chem. 2016, 64, 831-839. [CrossRef] [PubMed]

60. Lunder, M.; Bratkovic, T.; Kreft, S.; Strukelj, B. Peptide inhibitor of pancreatic lipase selected by phage display using different elution strategies. J. Lipid Res. 2005, 46, 1512-1516. [CrossRef]

61. Lunagariya, N.A.B.; Patel, N.K.; Jagtap, S.C.; Bhutani, K.K. Inhibitors of pancreatic lipase: State of the art and clinical perspectives. EXCLI J. 2014, 13, 897-921. [PubMed]

62. Moreno Valdespino, C.; Gonzalez de Mejia, E.; Mojica, L.; Luna-Vital, D.; Camacho, R. Bioactive peptides from black bean proteins play a potential role in the prevention of adipogenesis. Curr. Dev. Nutr. 2019, 3 (Suppl. 1), P06-119-19. [CrossRef]

63. Carrera, I.; Cacabelos, R. Current drugs and potential future neuroprotective compounds for Parkinson's disease. Curr. Neuropharmacol. 2019, 17, 295-306. [CrossRef]

64. Lee, E.J.; Lee, J.Y.; Seo, S.R.; Chung, K.C. Overexpression of DSCR1 blocks zincinduced neuronal cell death through the formation of nuclear aggregates. Mol. Cell. Neurosci. 2007, 35, 585-595. [CrossRef]

65. Chan, S.; Kantham, S.; Rao, V.M.; Palanivelu, M.K.; Pham, H.L.; Shaw, P.N.; McGeary, R.P.; Ross, B.P. Metal chelation, radical scavenging and inhibition of A $\beta 42$ fibrillation by food constituents in relation to Alzheimer's disease. Food Chem. 2016, 199, 185-194. [CrossRef]

66. González-Sarrías, A.; Núñez-Sánchez, M.Á.; Tomás-Barberán, F.A.; Espín, J.C. Neuroprotective effects of bioavailable polyphenolderived metabolites against oxidative stress-induced cytotoxicity in human neuroblastoma SH-SY5Y cells. J. Agric. Food Chem. 2017, 65, 752-758. [CrossRef]

67. Sheng, J.; Yang, X.; Chen, J.; Peng, T.; Yin, X.; Liu, W.; Liang, M.; Wan, J.; Yang, X. Antioxidative effects and mechanism study of bioactive peptides from defatted walnut (Juglans regia L.) meal hydrolysate. J. Agric. Food Chem. 2019, 67, 3305-3312. [CrossRef] [PubMed]

68. Feng, L.; Peng, F.; Wang, X.; Li, M.; Lei, H.; Xu, H. Identification and characterization of antioxidative peptides derived from simulated in vitro gastrointestinal digestion of walnut meal proteins. Food Res. Int. 2019, 116, 518-526. [CrossRef]

69. Lee, S.Y.; Hur, S.J. Neuroprotective effects of different molecular weight peptide fractions obtained from beef by hydrolysis with commercial enzymes in SH-SY5Y cells. Food Res. Int. 2019, 121, 176-184. [CrossRef]

70. Lee, S.Y.; Hur, S.J. Protective effect of a $3 \mathrm{kDa}$ peptide obtained from beef myofibrillar protein using alkaline-AK on neuronal cells. Neurochem. Int. 2019, 129, 104459. [CrossRef] [PubMed]

71. Wang, H.; Shao, B.; Yu, H.; Xu, F.; Wang, P.; Yu, K.; Han, Y.; Song, M.; Li, Y.; Cao, Z. Neuroprotective role of hyperforin on aluminum maltolate-induced oxidative damage and apoptosis in PC12 cells and SH-SY5Y cells. Chem. Biol. Interact. 2019, 299, 15-26. [CrossRef] [PubMed] 